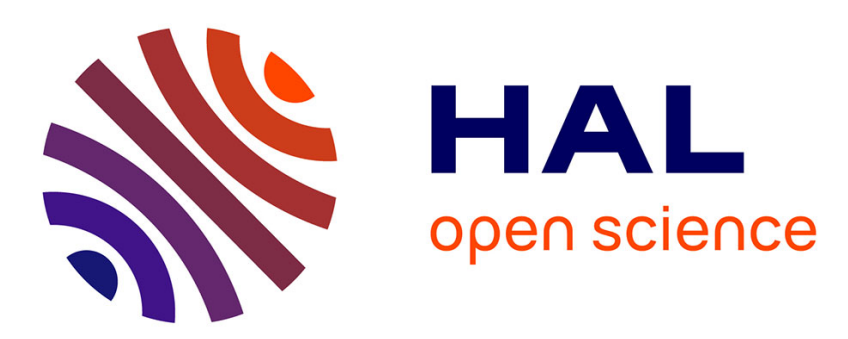

\title{
License Required: French Lesbian Parents Confront the Obligation to Marry in order to Establish Kinship
}

Michael Stambolis-Ruhstorfer, Virginie Descoutures

\section{To cite this version:}

Michael Stambolis-Ruhstorfer, Virginie Descoutures. License Required: French Lesbian Parents Confront the Obligation to Marry in order to Establish Kinship. International Social Science Journal, In press, 10.1111/issj.12241. hal-02916235

\section{HAL Id: hal-02916235 \\ https://hal.science/hal-02916235}

Submitted on 17 Aug 2020

HAL is a multi-disciplinary open access archive for the deposit and dissemination of scientific research documents, whether they are published or not. The documents may come from teaching and research institutions in France or abroad, or from public or private research centers.
L'archive ouverte pluridisciplinaire HAL, est destinée au dépôt et à la diffusion de documents scientifiques de niveau recherche, publiés ou non, émanant des établissements d'enseignement et de recherche français ou étrangers, des laboratoires publics ou privés. 


\title{
License Required: French Lesbian Parents Confront the Obligation to Marry in order to Establish Kinship
}

Michael Stambolis-Ruhstorfer, Université Bordeaux Montaigne

Virginie Descoutures, Université Picardie Jules Verne

\begin{abstract}
(200 words):
Before 2013, French children could not have two parents of the same sex. For example, nonbiologically related mothers in lesbian couples were legally invisible and prohibited to use second-parent adoption. A 2013 bill legalizing same-sex marriage and adoption authorized that option. However, this reform requires same-sex couples-but not heterosexual couplesto marry before establishing parental rights. Given this inequality, we ask: Compared to their heterosexual peers, do French same-sex couples with children marry more often? What do they think about same-sex marriage in general and their own marriages in particular? To answer these questions, we draw on survey responses and interviews from the first national cohort study of French same-sex couples, most of whom are lesbian, raising children born between 2011-2013 (n=162). We find significantly higher marriage rates among same-sex parents compared to different-sex parents. What may appear at first glance to be an unvarnished attachment to marriage is belied by discriminatory logics requiring couples to go against their stated ambivalence toward the institution of marriage in order to safeguard their parental rights. We argue that this burden is a form of legal violence that enforces heterosexist norms through legislation that was ostensibly enacted in the name of equality.
\end{abstract}

Keywords: queer families; second-parent adoption; same-sex marriage; France; law

In May 2013, after months of heated political debates and massive protests, French president, François Holland, signed into law a bill the Socialist majority in parliament passed authorizing same-sex couples the right to marry and adopt children. Many years in the making, this legislation marked a fundamental shift in French family law because, for the first time in the country's history, it allows children to legally have two parents of the same sex who can both enjoy the equal privileges that certified parenthood guarantees. Establishing what the French call filiation — often translated as "kinship" but whose specific meaning signifying both 
the legal and effective tie between a parent and child is difficult to translate - is the only way for an adult to have any significant institutional visibility as a parent. Since the new law was enacted, same-sex couples who are married can adopt children either jointly or-more commonly — the parent who is not biologically related can request a second-parent adoption, allowing him or her to be afforded equal parental status with his or her partner. Before this law, non-biological parents had little recognition in family courts and were subject to the whims of people within educational, medical, and other professional institutions as to whether they should be treated as a parent of their child. French gay and lesbian parents were thus at a comparative disadvantage to their peers in places like the United States, Denmark, and England where couples did not have to wait for the legalization of same-sex marriage before they could seek out second parent adoptions. This recent law provides French same-sex couples with the unprecedented opportunity to create legally protected families. Yet, because the law also requires that they first get married to establish filiation through second parent adoption — which heterosexual couples are not required to do-it forces them into an institution that they may or may not otherwise have sought. Moreover, this obligation continues to set French gay and lesbian families apart from their peers in other jurisdictions without such a marriage requirement.

Given this paradoxical situation, we ask: Compared to their peers in different-sex relationships, do French same-sex couples with children marry more often? What do they think about same-sex marriage in general and their own marriages in particular? Finally, what do their experiences teach us about how legalizing same-sex marriage addresses (or not) the inequality they face in French family law more broadly? To answer these questions, we draw on survey data with 162 French same-sex couples, most of whom are lesbian, raising children born in 2011, 2012, or early 2013, as well as on in-depth interview data with a subsample of 34 families within this group. Because their children were born just before the law was enacted, 
our respondents were among the first who had the option to marry and adopt and are therefore especially well placed to speak to our research questions.

\section{French Marriage and Adoption Laws and their Effect on Gay and Lesbian Families}

People who create families that do not conform to a two-parent heterosexual model face serious challenges for social, legal, and political recognition (Allen 2000; Goldberg 2010; Moore and Stambolis-Ruhstorfer 2013; Powell et al. 2016; 2010). Until policy changes to account for them, their relationships and kinship bonds go unrecognized, creating significant risk for the people involved. For same-sex couples in particular, securing the legal ties between both parents and the children is a complex, high-stakes endeavor and it is especially urgent for the parent without automatic statutory recognition (N. J. Mezey 2014; Malmquist 2015). Highlighting this, Descoutures (2010) distinguishes between the "statutory parent"-usually the mother who carried the child in a lesbian couples having used donor insemination, the father having used his sperm for surrogacy, or the parent who adopted the child while singleand the "non-statutory parent," sometimes imprecisely referred to as the non-biological parent. Despite their investment as parents on par with that of their partners, non-statutory parents are often in precarious legal circumstances. Consequently, establishing solid legal ties between the non-statutory parent and their children is a major concern for those who do not live in jurisdictions, such as Québec, where both parents in a same-sex couple can be automatically recognized as such on the child's birth certificate (Borrillo 2015; Descoutures 2010; Gross, Courduriès, and Federico 2014a; Malmquist 2015; Manning, Fettro, and Lamidi 2014; Moore and Stambolis-Ruhstorfer 2013; Gartrell et al. 1996). To overcome the vulnerability associated with their situation (Federle 2005; Malmquist and Zetterqvist 2013), in locations where it is allowed, the non-statutory parent can use second parent adoption, which generally gives the full benefits of legal parenthood. 
Before the legalization of second parent adoption—2013 in France — or in places where it is not an option, same-sex couples must resort to complex and often tenuous legal solutions in the hope of ensuring that, say, if the statutory parent dies, the non-statutory parent will get custody of their children (S. G. Mezey 2009; Perrin 2002). Second parent adoptions are correlated with a variety of positive outcomes both for children and parents. Research suggests, for example, that among lesbian mothers, custody arrangements are more equal between them in the case of separation (Gartrell et al. 2005) and that children report feeling closer to both parents (Gartrell et al. 2011). Given these effects, it is logical that same-sex couples, and in particular non-statutory parents, would seek out second-parenting adoptions where possible. However, research also suggests that accessing second parent adoption can be fraught with difficulty. Because the process can be costly and complicated, it often requires cultural and economic resources (Moore 2011). Furthermore, even in jurisdictions such as Sweden, Belgium, or Spain where second parent adoption and gay parenting has been legal for over a decade, lesbian mothers can be met with skepticism or resistance by administrators (Malmquist 2015; Messina and D’Amore 2018).

The rights of same-sex couples to create and protect their families have only recently been recognized in France. The French government legalized same-sex marriage and adoption for same-sex couples in 2013, under socialist president François Hollande and the Socialist Party majority in the Assemblée Nationale. French marriage and adoption laws are linked together. Only single people and married couples can access full adoption (adoption plénière). Thus, prior to the 2013 law, same-sex couples had no legal option in order to allow for both partners to have the same protections and obligations toward their children. Although couples could sign a Pacte civil de solidarité (Pacs), a civil union system legalized in 1999, this contract has no impact on ties between parents and children and is not used when determining custody or other parental matters. Same-sex couples have used "simple adoption" (adoption simple)— 
in which a person over the age of 18 can be adopted for inheritance purposes - as well as delegation of parental authority — where a parent temporarily delegates a part of his or her decision-making power over their child to someone else — but both are legally fragile and have limited consequences in terms of parenting rights. Finally, as of June 2020, the French government still forbids lesbian couples - but not heterosexual couples-from accessing assisted reproductive techniques in France and surrogacy is banned completely. French lesbian couples seeking artificial insemination, for example, must go abroad, usually to Spain or Belgium, or order sperm from sperm banks in Denmark (Gross, Courduriès, and Federico 2014a). Table 1 summarizes the French legal situation before and after passage of the 2013 marriage law.

\begin{tabular}{lcc}
\hline $\begin{array}{l}\text { Table 1: Legal Recognition for Same-Sex Headed } \\
\text { Families in France }\end{array}$ & \\
\hline & Before 2013 law & After 2013 law \\
\cline { 2 - 3 } $\begin{array}{l}\text { Pacs (Civil unions) } \\
\text { Yes }\end{array}$ & Yes \\
Marriage & No & Yes \\
$\begin{array}{l}\text { Joint adoption } \\
\text { Second parent adoption }\end{array}$ & No & Yes \\
$\begin{array}{l}\text { "Simple" adoption (of } \\
\text { children over 18) }\end{array}$ & Yes & Yes \\
$\begin{array}{l}\text { Delegation of parental } \\
\text { authority }\end{array}$ & Yes & Yes \\
$\begin{array}{l}\text { Medically assisted } \\
\text { couples / single women }\end{array}$ & & No \\
\hline
\end{tabular}

In contrast to same-sex couples, different-sex couples in France have no need to either marry or use second-parent adoption to ensure that both parents are recognized as equal parents of their children in the eyes of the law. Women who give birth are automatically recognized as 
the mother of the child and if there is a father, the man simply has to declare to the authorities (Etat Civil) his paternity (regardless of whether he is genetically related to the child). If married, the husband is automatically considered the father of the children his wife births according to presumption of paternity laws passed in 1972. Furthermore, with the significant exception of parenting rights and filiation (legal establishment of parent-child kinship ties), the Pacs provides most of the same rights as marriage to the two adults involved. The Pacs opens tax and inheritance rights, mutually required solidarity between partners, institutional visibility as a couple, and shared welfare benefits. Moreover, entering into a Pacs requires less paperwork than marriage and can be unilaterally broken by one of the partners who simply sends a notarized letter to the court. As a result of these advantages and low cost, different-sex couples have increasingly preferred the Pacs (Rault 2019). For example, in 2016 there were 410,495 different-sex couples who formalized their unions. $44.4 \%$ of these were Pacsed and $55.6 \%$ were married. ${ }^{1}$ Moreover, the relative proportion of different-sex couples getting Pacsed instead of married is increasing over time. Furthermore, and perhaps surprisingly for readers in countries like the United States - with relatively low out-of-wedlock birthrates - of the 783,640 children born in France in 2016, 59.7\% were born out of wedlock. ${ }^{2}$ This suggests that most French heterosexuals do not take the step of marrying when creating their families, which may be due to the relatively few benefits it provides to heterosexual parents.

Conversely, for same-sex couples, there is no option for both parents to automatically be recognized upon the birth of the child (Borrillo 2015; Gross 2017). In the case of lesbian couples having used medically assisted procreation, only the mother having carried the baby is legally recognized. If the couple is married, the non-statutory mother must go through the complex process of legally adopting the child as the second parent. The situation is similar for

\footnotetext{
${ }^{1} \mathrm{https}: / / \mathrm{www}$. insee.fr/fr/statistiques/2381498

${ }^{2} \mathrm{https}: / / \mathrm{www}$. insee.fr/fr/statistiques/2381394\#tableau-Donnes
} 
two men having used a surrogate mother abroad. Only the genetically related father is recognized by the law when the child is born. In both cases, if the couple is not married, the non-statutory parent has very few options, none of which provide full parental rights.

France is among what appears to be a minority of countries that requires that same-sex couples marry before they be allowed access to second parent adoption. Although crossnational legal comparison in family law is especially difficult because of a rapidly changing and complex legal landscape, research by Waaldijk (2017) and his colleagues provides an analysis of a sample of European countries. Taking their data and adding to it, Table 2 shows that only four out of a sample of eighteen European countries currently require marriage in order to second-parent adopt. That France is requiring marriage for same-sex couples even as it does not require the same of different-sex couples not only places the country among the legal minority. It also begs the question of how the legalization of same-sex marriage in certain countries can create forms of heterosexist discrimination and stigmatization under the guise of equality. 


\section{Table 2: Sample of European Countries Authorizing Second- Parent Adoption for Same-Sex Couples}

\begin{tabular}{lcc}
\hline & $\begin{array}{c}\text { Marriage/Civil Union } \\
\text { Required } \\
\text { to Adopt }\end{array}$ & $\begin{array}{c}\text { Marriage/Civil Union } \\
\text { Not Required } \\
\text { to Adopt }\end{array}$ \\
\cline { 2 - 3 } Austria & & $\mathrm{X}$ \\
Denmark & & $\mathrm{X}$ \\
Belgium & $\mathrm{X}$ & $\mathrm{X}$ \\
Finland & $\mathrm{X}$ & \\
France & & \\
Germany & & $\mathrm{X}$ \\
Iceland & & $\mathrm{X}$ \\
Ireland & & $\mathrm{X}$ \\
Italy & $\mathrm{X}$ & $\mathrm{X}$ \\
Malta & & $\mathrm{X}$ \\
Netherlands & & $\mathrm{X}$ \\
Norway & & $\mathrm{X}$ \\
Portugal & & \\
Suisse & & $\mathrm{X}$ \\
Slovenia & & $\mathrm{X}$ \\
Spain & & $\mathrm{X}$ \\
Sweden & & $\mathrm{X}$ \\
UK & & \\
\hline \multicolumn{1}{c}{ Sources: K. Waaldijk et al. (eds.), The LawsAndFamilies Database - Aspects of legal family formats for } \\
same-sex and different-sex couples. Paris: INED, 2017, http:/www.LawsAndFamilies.eu. Updated.; \\
http://journals.openedition.org/revdh/3699; Cortina 2016.
\end{tabular}

\section{Understanding Same-Sex Headed Families Across Contexts}

Like other socially marginalized family formations (Lauster and Easterbrook 2011; Amato 2010; Biblarz and Stacey 2010), the relationships of gays and lesbians have provoked political battles and incited scholarly attention that now spans several decades. Across the ideological spectrum, advocates and opponents of gay and lesbian families have wondered whether same-sex couples should invest in or be allowed to formalize their unions through the traditional avenues of heteronormative institutions such as marriage and adoption (Badgett 
2009; Baunach 2012; Bernstein and Taylor 2013; Duggan 2002; Paternotte 2011; Polikoff 2008; Warner 1999). In this polarized context, gay and lesbian relationship characteristicstheir stability, family structures, and outcomes — have garnered much scholarly attention in part because this information informs the political process (Biblarz and Stacey 2010; Gates 2015; Manning, Brown, and Stykes 2016; Stambolis-Ruhstorfer 2015). Understanding processes of family formation across same-sex and different-sex headed families is therefore important.

Lack of social and legal support—sometimes called "incomplete institutionalization" (Biblarz and Savci 2010; Manning, Brown, and Stykes 2016) —as well as raising children together in an intentional family, are both key factors that affect gay and lesbian relationships. Yet both are also related to one another in complex ways that also vary systematically across national context. Specifically, legal frameworks and public opinion on gay marriage, on the one hand, and gay parenting, on the other, differ by country. For example, public opinion on these issues has long been flipped between the United States and France (Stambolis-Ruhstorfer 2015; Stambolis-Ruhstorfer and Tricou 2017). Until the last half decade, in public opinion surveys American respondents rejected same-sex marriage but accepted same-sex adoption while the French were favorable toward same-sex marriage but expressed hostility to same-sex adoption. Moreover, these differences sometimes trace onto patterns of legalization. In the United States, long before same-sex couples could marry, in some jurisdictions, same-sex couples could secure their ties to their children through second parent adoption. In contrast, in France, adoption, whether joint or second parent, is contingent on marriage.

Across contexts, same-sex parents take many legal and administrative steps to ensure their families are protected against threats, including, for example, questions about custody or inheritance in the case of death of one of the parents (Gross 2017; S. G. Mezey 2009). Making these plans, however, depends on circumstances. Understanding the institutional and cultural specificities of different national contexts is therefore essential if we are to understand the 
conditions that shape the motivations and experiences of same-sex couples as they attempt to secure their families in the eyes of the law. The French case offers the opportunity to examine how French requirements to marry to access second parent adoption impact gay and lesbian couples' decision making.

\section{National patterns in Same-Sex Marriages}

Comparing formal family formation across couple types and across contexts is especially challenging because of high levels of variability across cases. Unlike their differentsex peers, same-sex couples have only recently had access to precisely the same relationship rights and recognition, and only in certain countries. This can create biases in cross-national and cross-group comparison. For example, there may be pent up demand for marriage in some contexts with recent legalization or generational differences as the novelty of same-sex marriage wears off in others (Badgett 2009; Kolk and Andersson 2018). In addition, legal and cultural differences over marriage and the benefits it provides (or not) make cross-national comparison difficult to interpret. Understanding couple formation, such as marriage rates, thus requires careful attention to context. Indeed, Gates $(2015,69)$ argues that "the social and legal climate may explain a great deal about why same-sex couples behave differently from different-sex couples in terms of relationship formation and stability." Analyzing families in France, where parenting rights are different for same-sex and different sex couples, offers the opportunity to test the impact of a more constraining national context on the way same-sex couples make decisions about marriage.

Raising children is a significant factor impacting how couples of all sexes behave in their relationships both in terms of whether they formalize or dissolve them (Andersson et al. 2006; Kalmijn, Loeve, and Manting 2007; Manning, Fettro, and Lamidi 2014; Ross, Gask, and Berrington 2011; Wiik, Seierstad, and Noack 2014). Presence of children can create an 
incentive to get married, especially in contexts where marriage impacts parenting rights, and constitute a barrier to separation (Kurdek 1998). Recent work on Norway, for example, confirms that divorce rates for lesbian couples are significantly lower when couples are raising children together (Wiik, Seierstad, and Noack 2014). Yet this research does not consistently account for the ways in which marriage laws constrain and enable the ability of same-sex couples to secure their legal ties to their children, leaving the legal dimension of parenting rights and relationship formation less examined (Gates 2011a; Rosenfeld 2014). If same-sex and different-sex couples raising children are similarly situated legally then we might expect their marriage rates to be similar. But if their rights differ, as they do in France, where the incentive to get married for same-sex couples is higher, we can expect different levels of marriage across these groups. We analyze how French same-sex couples raising children respond to the legalization of same-sex marriage in a country where marriage is an obligation in order access second-parent adoption.

As countries and jurisdictions consider legalizing same-sex marriage, same-sex couples think about how those changes impact their relationships and their aspirations for creating families (Chetcuti 2010; Courduriès 2011; Descoutures 2010; Hull 2006). For example, findings from Pew Research Center Studies (2010) cited by Gates (2015) find that 56\% of unmarried gay men and $58 \%$ of unmarried lesbians hoped to get married one day. This rate was higher than for unmarried people in the general population $(46 \%)$. These data were gathered before the legalization of same-sex marriage nationally in the US and reflect aspirations to marriage rather than marriage rates themselves, which appear to be lower. According to 2015 Gallop survey estimations cited by Gates (2015), approximately $40 \%$ of same-sex couples in the United States were married, though the accuracy of these data must be taken into consideration. Marriage trends in the US do suggest increasing rates for same-sex couples over time. American same-sex couples motives appear to be centered on access to 
rights and benefits including financial and tax incentives, spousal health insurance, and other policies relative to marriage in the US whose scant welfare state heavily relies on marital status in the distribution of benefits (Gates 2015; Pew Research Center 2010). In other words, samesex couples are not citing access to parenting or legally securing the relationships between parents and children as among their primary reasons to marry.

Research on Spain provides some evidence to suggest that parenting may be part of that decision-making process. According to 2011 Spanish census data, same-sex couples are less likely to be married than different-sex couples (Cortina 2016). While $89 \%$ of different-sex couples living together were formally married, $45.8 \%$ of gay couples and $43.7 \%$ of lesbian couples were. Although marriage rates were thus lower among same-sex couples overall, samesex couples raising children were more likely to be married. The probability of same-sex couples cohabiting and not marrying was $60 \%$ higher if they did not have children (Cortina 2016, 18). Presence of children thus appears to impact Spanish same-sex couples' decisions to marry. Without qualitative data exploring the reasoning behind what motivates same-sex couples raising children to marry, it is unclear whether these Spanish couples do so in order to have access to second parent adoption or for other reasons. Cortina (2016) states that further research is necessary to untangle the role of reproductive decision-making for same-sex couples and the way it shapes their perspectives on marriage. We ask how same-sex couples raising children in France, where marriage is a prerequisite for securing the rights non-statutory parents through second-parent adoption, might think about marriage.

\section{Critiques of marriage}

Depending on its context and implementation, same-sex marriage might not be an unqualified opportunity with only positive effects for same-sex couples and their children (Ocobock 2013). Some of its potentially problematic aspects are linked to the institution of 
marriage itself. Indeed, as feminist and queer critics have long argued, marriage has traditionally been a lynchpin in patriarchal systems of domination, reproducing and maintaining forms of racial, class, and gender inequality (Barker 2012; Bourcier 2012; Brown 2009; Duggan 2002; Walters 2014; Warner 1999). One critique typically centers on the fact that LGBTQ people have invented novel forms of kinship that breakdown heterosexist conceptions of the two-parent, biologically related family (Carrington 2002). From guild families, co-parenting families, or chosen families (Gahan 2019; Hull and Ortyl 2019), these unique family forms can be more inclusive, defying the conventional norms of marriage. Much has been written about whether legalizing same-sex marriage might lead to the erasure of these families, creating a new hierarchy among married and unmarried same-sex couples raising children and thereby creating a form of homonormativity, on the one hand, or make the institution of marriage less implicated in maintaining forms of domination on the other (Barker 2012; Barker and Monk 2015; Duggan 2002; Walters 2014).

Same-sex couples are caught in these tensions. Many gay men and lesbians, particularly those with feminist commitments, de-prioritize the legalization of same-sex marriage and argue instead for more fundamental social and political change (Warner 1999; Bernstein and Taylor 2013). At the same time, some who are critical of marriage as an institution also argue that same-sex couples should be allowed to marry as a matter of equality (Hull 2006; Ocobock 2018). Now that same-sex marriage is legal in many jurisdictions, including France, we can better understand how same-sex couples deal with and think about marriage. It is important to focus on national variations in same-sex marriage laws, such as the requirement to marry in order to adopt, because these elements determine the degree to which marriage can generate new obstacles for-rather than meet the demands of - same-sex couples. We ask how those conditions shape the way couples perceive marriage as an option for their relationships and their thoughts about marriage as an issue of social justice more broadly. 


\section{Data and Methods}

The results presented in this article are based on data from the French national study entitled, DEVHOM (Homoparentalité, fonctionnement familial, développement, et socialisation des enfants), which was funded by the National Research Agency (ANR) and conducted by an interdisciplinary team of over a dozen social scientists, including the two authors. The DEVHOM data includes both a quantitative survey and in-depth interviews. The surveys were conducted online as well as during in-person visits in respondents' homes. Respondents were all in same-sex relationships and were raising at least one child that had been born in 2011, 2012, or early 2013 and hail from all regions of France. We chose this birth year because it allows for us to systematically compare our results with those of the French national cohort study ELFE (Etude longitudinale française depuis l'enfance), which was launched in 2011 and follows over 18,300 children born in mainland France and measures children's emotional, psychological, and cognitive development as well as their socialization within their families, at educational institutions, and among their peers. The ELFE study recruited children through a random sample of women having given birth in French maternity wards and only yielded 16 children raised by two women. DEVHOM was conceived specifically to increase the number of cases headed by same-sex couples to compensate for this underrepresentation.

The gay and lesbian families in the DEVHOM sample $(n=162)$ were established in a variety of ways including those who had children intentionally as a couple through medically assisted reproduction, those who adopted or conceived children as single parents, or those who had children through prior heterosexual relationships. Same-sex couples were recruited using a variety of methods, including: 1) online and in person outreach to French LGBT parenting organizations; 2) an advertisement in the newsletter sent to families receiving aid from the 
French national social services organization, la Caisse Des Allocations Familiales; 3) postings in online forums and social media; 4) messages on list serves; and 4) respondent-driven sampling (Heckathorn 2002). Finding suitable families was challenging because respondents are not only among a small, socially stigmatized minority but also because their children had to have been born within a narrow time frame.

The data were gathered in several phases. First, researchers visited respondents in their homes and administered two questionnaires, one in face-to-face interviews the other selfadministered. Second, approximately three months after the home visit, respondents received a third and final questionnaire to which they responded online. The qualitative data were gathered with a sub-sample of 34 families who agreed to in-depth semi-directive interviews, usually with both parents present, lasting between one and two and half hours and conducted at respondents' homes.

The DEVHOM survey sample is composed of 162 families, 9 of whom were raising twins born in the cohort years and 6 who had two children born in two different years, which gives a total of 177 children ( $43 \%$ of whom were born in $2011,39 \%$ in 2012 , and $18 \%$ in 2013 ). Table 3 describes the characteristics of the DEVHOM sample as well as the ELFE sample of different sex-couples. In the qualitative sub-sample of 34 families, there are 30 lesbian couples and four gay male couples who had between one and three children at the time of the interview. Sixteen had one child, thirteen had two children, and five had three children. The lesbian couples, with the exception of two who had co-parenting arrangements, used various forms of artificial insemination, either by going abroad or with known donors, to have children. The gay men had children through co-parenting arrangements with lesbian couples (3) and through surrogacy in the United States (1). The parents were born between 1963 and 1985. Two thirds were born in the 1970s. Their level of education is high. Only 4 parents had less than a high school education and 39 had a Bachelor's or Master's degree. All but three respondents were 
employed, most as salaried workers in the public and private sectors; 10 were self-employed professionals. With the exception of three families, respondents' household incomes were higher than the French national average for 2015 (36,000€/year), most earning between 5,000€ and $6,000 € /$ month.

\begin{tabular}{lrr}
\hline Table 3: Characteristics of DEVHOM and ELFE samples & \\
\hline & Different-sex Parents & Same-sex Parents \\
Mean age of mothers at birth & 31 & 35 \\
Mean age of fathers at birth & 33 & 41 \\
Household mean revenue/month & $3,643 €$ & $5,064 €$ \\
Socio-professional category of Mothers (\%) & 2 & \\
Independent worker & 17 & 4 \\
Higher managerial and intellectual occupations & 32 & 39 \\
Intermediate occupations & 41 & 42 \\
Employee & 8 & 13 \\
Worker & & 2 \\
Socio-professional category of Fathers (\%) & 8 & 5 \\
Independent worker & 24 & 55 \\
Higher managerial and intellectual occupations & 26 & 40 \\
Intermediate occupations & 14 & 0 \\
Employee & 29 & 0 \\
Worker & & \\
\hline
\end{tabular}

Source: ELFE $\mathrm{n}=18301$ different-sex headed families: 18301 mothers and 12678 fathers participating in the survey (means and percentages calculated on weighted totals); Devhom: $n=162$ families headed by same-sex couples: 257 mothers and 25 fathers participating in the survey. Socio-professional categories are based on The National Institute of Statistics and Economic Studies (INSEE) classifications.

It is impossible to know the degree of representativeness of our sample because there is no reference population and because the French census does not gather sufficient information on sexual orientation to make estimations. However, our sample includes families from all French regions as well as French rural and urban areas. One third comes from Ile-de-France, the region around and including Paris. Despite this geographic range, based on other studies of LGBT parenting in France (Gross 2017; Gross, Courduriès, and Federico 2014a; Gross 2015; $2012 ; 2011)$, as well as on population estimates from other countries, such as the United States 
(Gates 2011b; 2011a; Gates and Ost 2004; Goldberg, Gartrell, and Gates 2014), we suspect our sample may be biased in several ways.

First, in terms of gender, of the 162 responses, only 16 were gay male couples ( 4 of whom were also in the interviewed sub-sample). Although research suggests that more lesbians are raising children than gay men in general (Gross, Courduriès, and Federico 2014b), we cannot know whether the low number of gay men is an accurate reflection of the French samesex parenting population or the result of sampling bias. Because of the limited number of gay male couples in our study, especially in the qualitative sub-sample, our discussion focuses on the experiences of the lesbian couples. On the question of motivations to marry, our data do not allow us to speak in detail to the experiences of the men or to compare in terms of gender. Second, in terms of class, the DEVHOM sample includes more families with levels of education and income that are higher than the average in the French population. It is unclear whether this is representative of the French same-sex parenting population as a whole. Current French law requires lesbians and gay men to go abroad to access costly assisted reproduction and surrogacy services. Recent research suggests that most French couples do so (Gross, Courduriès, and Federico 2014a). It is therefore possible that same-sex couples raising children in France are wealthier on average than their different-sex peers.

This article draws on both the quantitative and qualitative data from DEVHOM. To answer our first - and most straightforward — research question, we draw on two survey items that deal with marriage: marital status and year of marriage. These questions were asked of both DEVHOM and ELFE respondents, allowing us to compare marriage rates and year of marriage across same-sex and different-sex couples raising children of the same age. One survey question was posed only to married same-sex couples asking them to identify their purposes for marrying. Responses hinted at the answers to our second and third research questions about the motivations and meanings of marriage, as well as their implications for 
broader issues of inequality. To more fully deal with the nuances of these questions and make sense of the marriage rates we observed, we drew on the rich and textured narratives from the interview data.

We used semi-directive interview guides to talk with parents about a range of issues including family formation, household division of labor, parenting styles, and interactions in neighborhoods and schools. This article focuses on themes in interviews dealing with their justifications for getting married, the effects and consequences of marriage for their families and children, as well as their experiences with legal and administrative institutions. The interviews were full recorded and transcribed. We collectively read the interview transcripts to identify and highlight common themes across the interviews. We then iteratively developed a general coding scheme with 128 items to completely code all of the transcripts in Nvivo. Our results explore codes dealing with the following themes: effects and consequences of marriage, separation and divorce, motivations for marriage, discrimination, differences between civil unions and marriage, visibility and social recognition of same-sex families, interactions with the state, and activism.

\section{French same-sex couples with children marry at high rates}

With the law legalizing same-sex marriage and adoption in France in 2013, same- and different-sex couples now find themselves in the same legal position and potentially within the same position in our study: both types usually began the study in relationships (married, Pacsed, or cohabiting) and all had at least one child born in 2011, 2012 or 2013. Despite this similar position, these two groups get married in significantly different proportions. The samesex couples in our sample have flocked to marriage in high numbers. As Table 4 shows, over $77 \%$ of the 162 same-sex couples in the DEVHOM sample are married while only $51.8 \%$ in the comparative ELFE sample (at year 2) of different-sex couples are. The out of wedlock 
childbirth rate for different-sex couples is thus comparable, if slightly lower, to the national data in France in 2016 cited above. The marriage rate for same-sex couples is over $25 \%$ higher relative to different-sex couples. This confirms our hypotheses that French same-sex couples raising children would likely get married at higher rates.

\begin{tabular}{|c|c|c|c|c|c|}
\hline \multirow[b]{2}{*}{ Married } & \multicolumn{2}{|c|}{ Same-Sex Couples } & \multicolumn{2}{|c|}{ Different-Sex Couples } & \multirow{2}{*}{$\begin{array}{l}\text { P value } \\
0.001^{* * *}\end{array}$} \\
\hline & 126 & $77.78 \%$ & 6,972 & $51.77 \%$ & \\
\hline Pacsed & 18 & $11.11 \%$ & 2,350 & $17.45 \%$ & $0.001 * * *$ \\
\hline Neither married nor Pacsed & 9 & $5.56 \%$ & 3,506 & $26.03 \%$ & $0.034 * *$ \\
\hline Not currently in relationship & 9 & $5.56 \%$ & 639 & $4.74 \%$ & 0.63 \\
\hline Total & 162 & & 13,467 & & \\
\hline
\end{tabular}

In addition to a high marriage rate, the majority of couples in our study got married quickly after same-sex marriage was legalized in France in May 2013. Of the 116 couples for which we have responses for the date of marriage, 47\% got married in 2013 in the 6 months after the law was passed, and 37\% got married in 2014 and 2015. In other words, more than $84 \%$ of these families wanted to get married as quickly as possible. That these same-sex couples raising children tied the knot in relatively high proportions and as soon as they were legally able indicates urgency and perhaps the satisfaction of a pent up demand. To explain what drove our respondents in such high numbers to their respective city halls, where all French marriages are publically officiated, we turn to the more nuanced question of their motivations and the meanings they attach to them.

\section{Constrained enthusiasm}

At first glance, the high marriage rate might suggest that same-sex parents are especially interested in marriage as an institution, particularly in a context where it is a newly acquired right. Relative to their peers in different-sex relationships, for whom marriage has always been a possibility, perhaps same-sex couples are more driven to get married precisely because of their history of exclusion from it. While this desire to right a historic wrong in a 
personal way is among the reasons some French lesbian couples bring up, their narratives show a complex web of sometimes contradictory perspectives about their marriages. As we describe below, many experience their marriages as both an unjust constraint and an opportunity to demonstrate their commitment publically. Above all, they turn to marriage to secure their legal relationships with their children because of the specificities of French family law.

Our survey data offer an initial glimpse at the hierarchies of their motivations. Married same-sex couples were presented eight justifications for their decision and asked whether or not (yes or no) each was a reason for their marriage. As Table 5 shows, of the 57 couples that completed all items in this question, the top justification for marriage was in order to compensate for the lack of legal protection and recognition for their families. These results suggest that although French same-sex couples get married for a variety of reasons, including for love and to show their commitment, the lack of legal protections for their parent-child relationships is especially important to them. Their responses underline a complicated coexistence between the necessity to get married to protect one's family, on the one hand, and the symbolic and emotional dimensions that legal marriage offers, on the other. To understand in greater depth this particular bind that French family law puts lesbian parents into, we turn to our interviews. 


\begin{tabular}{|c|c|c|}
\hline Table 5: Reasons for getting married & $\begin{array}{l}n=57) \\
\text { Yes }\end{array}$ & No \\
\hline $\begin{array}{l}\text { To compensate for the lack of legal protection } \\
\text { and recognition for your family }\end{array}$ & $87.72 \%$ & $12.28 \%$ \\
\hline For love & $75.44 \%$ & $24.56 \%$ \\
\hline To show my commitment to my partner & $68.42 \%$ & $31.58 \%$ \\
\hline For legal or financial reasons & $59.65 \%$ & $40.35 \%$ \\
\hline To show our commitment to others & $38.60 \%$ & $61.40 \%$ \\
\hline For political reasons & $35.09 \%$ & $64.91 \%$ \\
\hline To have a celebration & $21.05 \%$ & $78.95 \%$ \\
\hline To please your partner & $14.04 \%$ & $85.96 \%$ \\
\hline
\end{tabular}

When we analyzed the motivations and justifications that our respondents gave for why they married, we found that they were usually not attracted to marriage per se but rather to the specific parental rights that it allowed them to access that other options, such as the Pacs, could not provide. Indeed, unlike their peers in different-sex relationships, our respondents were required to marry to secure their family ties through second-parent adoption. Confirming their answers to the survey question, our respondents told us that they got married as quickly as possible in order to begin the long procedures for second-parent adoption. They sought to ensure that their children, almost all of whom were conceived through donor insemination, would have the legal protections of both their parents quickly. Indeed, until the second-parent adoption procedures are complete, the parent without legal status, even if he or she is married to the legal parent, is invisible in the eyes of French family law courts and other administrations.

For these reasons, we argue that marriage for lesbian couples in France functions as a “parenting license." It creates a required extra step specifically for same-sex couples-but not 
their different-sex peers - toward establishing full legal parentage for the both parents, and in particular those with non-biological ties to their children. This obligation to marry, which many of our respondents resent, does not necessarily preclude French lesbian couples from finding other forms of positive meaning in the institution. Indeed, as described below, many express feeling ultimately happy with the opportunity to celebrate - often for the second time for those who were already Pacsed - their relationships. However, it is clear that many would have preferred not to marry and the positive associations with marriage are akin to side effects of what becomes an institutional burden in the French context.

\section{Marriage: an "absolute necessity"}

For French lesbian couples raising children, marriage is not an option; it is a requirement. Although they consider the pros and cons, the idea that they can maintain their families without getting married seems impossible. Access to second-parent adoption is the main factor driving this sense of inescapability. Were it not for this factor, the families in our study would have likely taken more time to decide whether or not marriage was right for them. It appears that many would have decided against marriage. Indeed, of the 34 families that we interviewed, 20 said they would not have gotten married if they did not have children. Indeed, they explained that marriage was only interesting inasmuch as it opened the door to shared parenting rights and responsibilities. As one of our respondents, Rachel, explained, "I admit that [adoption] was the one and only reason. We had to get married so that Léo could be adopted... I never wanted to get married." Rachel's stance, clearly rejecting marriage even as she expresses an obligation to pursue it solely for the purposes of parenting, is common among our respondents. Many expressed disinterest in marriage when it came to their relationship as a couple. For example, Agathe and Caroline confirmed that as a couple marriage was not a priority: 
Agathe: We did it quickly, but not because we're big marriage enthusiasts.

Caroline: No, quite the contrary!

Agathe : ... But in order for me to adopt Gardélia... that is what was at stake. The marriage was in order to adopt. Otherwise, we probably wouldn't have gotten married...

Like Rachel, Agathe, and Caroline, the lesbian couples we interviewed ultimately got married with a certain amount of ambivalence, sometimes even reticence, and always with the feeling that it was an imposed bureaucratic step on the road to second-parent adoption.

The perception that they have no meaningful choice in the matter overshadows their position about the suitability of marriage for their relationships. The conversation between Anna and her wife Pascale illustrates this ambivalence in the context of what is a choice only in theory. During our interview, Anna said that, "Pascale didn't want to get married." In response, Pascale explained to us:

No it's not that I didn't want to get married. For me, I just wasn't especially interested in it. But, I understood that it was an absolute necessity in our case simply so that I could adopt Nathan since I'm not his biological mother.

So afterward, it's true that I wasn't really taken by all the symbolic things around marriage. For me, it's not really something that interested me.

For Pascale, gaining full legal status as Nathan's mother was essential and marriage, despite her disinterest in the institution generally, was the only way to achieve that goal. Thus, although she would have preferred to dissociate what she calls the symbolic aspects from her strictly utilitarian view, marriage and adoption become inextricable. Rejecting marriage could, therefore, be misinterpreted as a lack of investment in gaining the status as a legal parent. That enmeshing helps explain why Pascale seems to feel the need to defend her rejection of marriage to her wife Anna. In this context, lesbian mothers have to take specific care when articulating 
a critical or even non-committal position on marriage so as not to be misunderstood, especially because the legalization of same-sex marriage is framed as the outcome of a hard-fought battle for equality.

To deal with the fact that they had to enter into an institution that they rejected on principle or were apathetic toward, many respondents circumscribed marriage to its strictly practical purposes for parenting. This allows them to do what needs to be done for their families while maintaining their critical stances on marriage. For instance, many respondents were explicit in their claims that they did not need marriage, an institution some qualified as heteronormative and traditional, to give legitimacy to their relationships. Nathalie, whose critical view of marriage was shaped by the experiences of her own parents, exemplifies this posture. She said:

My parents were divorced so you know I always said to myself "I'll never get married.” And also on the institutional level, I don't think I need someone to tell me... for my relationship to exist, I don't need the state to recognize it.

Like many of the parents we interviewed, Nathalie had a long-standing position against getting married grounded in personal experience and intellectual justifications. She rejected the notion that she needed official state recognition in the form of marriage to consider her relationship with her partner as valuable and worthy of respect. This was a position she and other respondents like her could put into practice when same-sex marriage was illegal and likely would have continued had they and their partners not had children. But as mothers in a context without any other way for same-sex couples to have joint recognition as the legal parents of their children, they have to find a way to accept marriage without embracing the things about it - its links to heteronormative oppression and homonormativity-that they oppose. In sum, the institutional requirements in France generate a strong tension between what is preferable 
as a couple — not to get married — and what is required for the good of the family — getting married in order to second-parent adopt — that forces these women to prioritize their values as mothers ahead of their principles against marriage.

\section{(In)sufficiency of the Pacs and the reinforcing of heterosexual privilege}

In theory, the Pacs exists as a suitable alternative to marriage, and as described above, it attracts many different-sex and same-sex couples. Yet, because of their status as parents, our respondents did not see it as a feasible way to protect their families. In the words of Myrielle, "We were Pacsed and that was good enough for us. [Marriage], that's mainly for children." Most saw the Pacs as strong enough to safeguard the relationship between themselves and their partners, describing how its material and symbolic consequences were sufficient for them. Indeed, before marriage was legalized, many of our respondents were already Pacsed and talked about signing and celebrating these unions as a key moment in their relationships. Moreover, because the Pacs was made legal as a specific response to LGBT mobilization in the 1990s in the face of serious anti-gay resistance, our respondents already attached symbolic associations of legal victory to these unions. However, as described previously, the Pacs has no legal impact on creating parenting status for, say, non-statutory mothers, and does not allow for adoption as a couple or as a second-parent. This situation thus specifically limits the attractiveness of the Pacs as a tool for creating legal parent-child ties for our respondents.

They discussed these limitations of their Pacs even as they expressed reluctance about getting married. In particular, their narratives bring to light their concern that others may think they were not as invested in their relationships before the wedding. For this reason, they make clear that marriage was not something they sought as a couple but rather as parents. For example, like many of the couples we interviewed, Doriette and Isabelle were already Pacsed and got married grudgingly. Doriette explained, "Yes we were Pacsed and we didn't 
necessarily need to get married. I mean, it wasn't, well we didn't need it in order to tell ourselves that we were building a relationship together. And so it really was to make adoption possible." As with other couples, Doriette was insistent in denying the idea that before being married, their relationship was somehow less meaningful or serious. Isabelle, her wife, confirmed the idea that in terms of their relationship to each other, they "neither wanted to get married nor had emotional need for it." Other couples expressed their view that marriage did not add value to their relationships other than its effect on kinship. For example, when we asked Diana about her marital status, she told us: "Yes we were Pacsed. You know, for me, marriage doesn't really mean much. What I mean is, we didn't have all that symbolism in it that some people probably feel. I didn't need that. So it really was for adoption." This idea that marriage is useful only because of access to adoption is reflected in Tina and Christine's decision not to get married. At the time of our interview, they were raising their children jointly with a gay male couple, one of whom is the biological father. Because the children already have two parents on their birth certificates (Tina and one of the fathers), Christine cannot adopt their children. Because second-parent adoption is not an option, getting married does not make sense for them as a couple. Tina, explained:

If we get married just to get married, or if we get married to adopt the kids, that's not the same thing. For us, if it were getting marriage just for the sake of marriage, we're Pacsed and that's good for us. And getting married to adopt the kids is pointless since there is no possibility for adoption.

Tina and Christine's view of marriage, and their decision not get married, echoes the views of the married couples we interviewed. It confirms the idea that for these lesbian couples, marriage is a means to an end for parenting and not a way to affirm their relationship romantically. It reinforces the idea that these couples experienced their Pacs celebrations as 
emotional and romantic commitments, and, coupled with their critiques of marriage itself, were less likely to imbue their marriages with a special romantic meaning.

The view that our respondents express of the Pacs as a good enough for their relationships but insufficient for their families must be understood in the context of same-sex marriage as new form of inequality in France. Indeed, French same-sex couples are at a comparable disadvantage to different-sex couples who can secure their parenting rights without marriage or second parent adoption and have all of their other needs met with the Pacs. In other words, the state requires of same-sex couples — but not different-sex couples - that they prove their suitability to be legitimate parents by first getting married. In this way, marriage functions as a kind of "same-sex parenting license" that puts an unequal burden on French gay and lesbian couples. It also prevents them from organizing their families in other ways-via the Pacs or union libre (cohabiting unmarried/unPacsed)—with the same freedom as different-sex couples.

\section{Separation: relationship timing and the barrier of marriage}

The requirement that same-sex couples get married in order to adopt creates a specific problem for French couples when children are born before parents are married. This is the case for all of the respondents in our cohort because their children were born before same-sex marriage was legalized. The problem comes about when parents separate before getting married, thus leaving the non-statutory parent without any recognized parental status because they could not adopt the children before the separation. We discussed this situation with Corinne who described to us why she did not want to marry in 2013 after marriage became legal. We asked her if she thought about getting married, and she answered:

No because once marriage was possible, [our relationship] wasn't working anymore. Actually, I thought it was stupid to get married right at the 
moment when the only thing I wanted was to get the hell out of there. So we didn't get married because when we would have wanted to get married, only the Pacs was legal. When marriage became an option, we were already talking about getting separated. So that's why we didn't get married.

Interviewer: The reason I ask is because it's the only way to be able to adopt.

Yes I know

And so, what about your [ex]partner?

She sees him because I let her see him. There you have it. She takes him one or two nights a week, sometimes for the holidays.

Corinne, who gave birth to their child, and her ex-partner were on the verge of breaking up without any parental rights for the non-statutory parent. Had they been married and gotten a second-parent adoption before separating, they could have both benefited from the legal framework for a divorce and custody decision that would have prevented Corinne from making unilateral decisions about their child and would have allowed her ex-partner, currently invisible in the eyes of the law, to be recognized as a mother.

Unequal separations favoring statutory (usually biological) parents was — and still is — the norm for same-sex couples in contexts where there is no formalized process, or one that depends entirely on biased justice systems, for protecting the rights of parents without genetic ties to their children (S. G. Mezey 2009). The legalization of same-sex marriage and adoption in France in 2013 ended such discriminatory statutory situations in theory. But, by requiring that only same-sex couples — and not heterosexual couples — both marry and adopt to establish legal status across parents, French legislation reproduces the heterosexist logics, albeit in a more subtle way, that justified prohibitions of same-sex marriage and parenting in the first place. Moreover, to ensure that both parents are recognized in the case of separation, couples 
like Corinne's would first have to marry, go through adoption procedures, and then divorce in order for the judge to consider the non-statutory parent as having an actionable relationship to their child. No one in our sample chose to go through this complicated and paradoxical process.

\section{Marriage as tool for visibility and activism despite constraints}

Although most of our respondents treated marriage as a means to an end and took a critical stance both as to its requirement and meaning for their relationships, some also embraced it as an opportunity, despite its drawbacks, to send a political message to those around them. In this way, like couples in other studies (Hull 2006; Olsen 2014), getting married, including the ceremony itself, constituted a form of activism for our respondents. In the French context marked by large anti same-sex marriage protests and reactionary political discourse in the lead up to the passage of the 2013 marriage bill, many respondents said that getting married was an opportunity to publically state that their families exist and deserve recognition. Even as they recognized the injustice of having to get married despite their preference not to, many saw value in the fact that same-sex marriage was a major step toward formal equal rights. For example, Nathalie, who would have preferred not to get married, said, "At the same time, I'm really attached to equal rights and the equality of the law," as she was explaining how she felt after her marriage.

Because the new law would permit children to legally have two parents of the same sex — via second parent adoption—-for the first time in French history, many respondents felt their marriages would give them new legitimacy in the public sphere. It would now be impossible for opponents to deny the existence of gay and lesbian families. This stance was made especially meaningful because debates over same-sex marriage centered primarily on the suitability of same-sex couples to raise children (Fassin 2014; Robcis 2015). Dominique's explanation of how she came to embrace the power of her marriage-despite seeing it as an 
unavoidable necessity-illustrates how some respondents progressively came to see their marriages as a way of expressing their right to a recognized social status as a family. She explained:

You know, we couldn't even stop to ask ourselves the question because we wanted to adopt the children so badly that maybe we wouldn't have... Well we'll never know but there was the Pacs and that filled many of our expectations. The Pacs was important. It's true that marriage gives a few more advantages and there is also the symbol. In the beginning, I'm not sure if we would have done it if we didn't have kids. But, once we did it, we said it was really a good thing that we did because we had a beautiful party. We really did have a marriage like everyone else. So we didn't regret it at all.

Like the majority of the lesbian couples we interviewed, Dominique and her wife got married with the primary goal of starting second parent adoption procedures. As with the other respondents, they felt their needs were met as a couple with the Pacs. Yet, despite that utilitarian view, they ultimately embraced celebrating their wedding and used it as an opportunity to make their family more legible to outsiders, including institutions and people close to them. They said it also gave them a feeling of social inclusion.

Many couples in our study used their marriages strategically to send a message of refusal to accept marginalization. Pascale, who as we saw in the conversation above with her wife Anna was not interested in marriage beyond its effects on parenting, explained how their wedding was an opportunity to make a political statement. She said, "We have a family, especially on my side, that is very conservative politically. And so all of this on a symbolic level was very important for us." As is French custom, the mayor of their city married them in a public ceremony. Pascale and Anna expressed feeling satisfied that he had to perform the marriage despite his public stance against same-sex marriage. Pascale explained, 
“...symbolically, because it was someone who was evidently not really in favor [of same-sex marriage] and who, in the end, had to confront the reality of things... So, you see, it was a little bit of a political act on our part!" This political dimension to their marriage was accompanied by what they describe as real joy in the event itself, which they celebrated with 130 guests on a riverboat. Anna described how once she and Pascale decided to marry, they enjoyed it. She said, "I invested all of my energy into preparing the wedding with a girlfriend of mine. It was great!" Anna and Pascale's story about their wedding demonstrates how French lesbian couples can simultaneously criticize marriage as an institution, resent having no choice if they want to protect their children, but also seize the opportunity to make a political statement about the legitimacy of their family and take joy in the occasion.

\section{Conclusion}

Our survey and interviews with 162 French same-sex couples, most of whom were women, and raising children born in the years just before the legalization of marriage and adoption reveal that this group is especially preoccupied with ensuring that their families are legally secure in the eyes of French institutions. As soon as they were able, these couples got married and at rates much higher than those of their peers in different-sex relationships raising children of the same ages. Their apparent attachment to marriage, however, is belied by discriminatory structures built into the new French marriage laws that place specific burdens on same-sex couples, requiring them to marry before they can begin second-parent adoption procedures in order to establish full parentage for both parents. This legal constraint to marry forces these women to go against their rejection or ambivalence toward marriage as an outdated or patriarchal institution in order to safeguard their parental rights. We argue, therefore, that this marriage requirement works as a form of symbolic violence that perpetuates heterosexism 
by specifically burdening same-sex couples even as the new legislation was enacted in the name of equality.

The effects of this "marriage license required" mode of establishing parenting rights have important consequences for same-sex couples and their children. We find that it means parents must consider the order in which they organize their reproductive and relationship plans. For example, lesbian couples who plan to have children via artificial insemination must now plan on marrying before beginning inseminations in order to begin second-parent adoption proceedings quickly after birth. We suspect that French lesbian couples who plan on having children will likely get married as a part of their process in becoming mothers. In instances where children are born before couples marry and adopt, as was the case for all respondents in our sample, separation places non-statutory parents in legal limbo. All of these issues can have potentially negative consequences for the social and psychological wellbeing of these families.

Until French law changes to allow lesbian couples to establish kinship ties with their children without the requirement to marry, they will be forced to enter into an institution that most would otherwise choose to opt out of. This requirement means that they can criticize marriage but have to go against their ideological commitments in order to protect their families. The state obligation to marry does not mean that lesbian couples do not find meaning and value in their marriages or even use them as opportunities to stake a visible claim to public legitimacy. It does, however, shape in important ways how they engage with marriage symbolically and strategically as a means to an end.

More broadly, the requirement to marry reinforces inequalities between same-sex and different-sex couples in ways that reproduce heterosexist logics about the superiority of sex differences and the supposed supremacy of biological relatedness. Indeed different-sex couples are given the benefit of the doubt about the validity of their parent-child relationships. For example, the man who claims to be the biological father to the authorities is granted full legal 
status as the father of the child his partner gives birth to without any requirement they be married or go through second parent adoption procedures. Thus, in contrast to same-sex couples, different-sex couples can rely on the assumptions of biological parenting and the preeminence of gender differences in their relationships. As a result, they have more options and flexibility in picking which institutions, if any, they will use to protect their relationships. Furthermore, even as out of wedlock childbirth has become the new norm for French different-sex couples, the French state is forcing lesbian couples who use artificial insemination do things in the traditional order-getting married before having children - to ensure their families are fully recognized. Same-sex marriage was framed as a new form of equality but without a more global rethinking of French family law to allow for a variety of family formations, including multi-parent families, current law will continue to be discriminatory. Québec, where lesbian couples can jointly declare their status as co-mothers of a child conceived through artificial insemination and carried by one the partners is a good example of a starting place for legal thinking that meets the needs of same-sex couples. Other countries, including Sweden and Germany, which used to have similar marriage or partnering requirements as France, have both modified their laws in recent years to remove them. French family law is increasingly an outliner in Europe on this issue.

Our research has implications for theoretical debates about legal institutions and family formation, queer critiques of same-sex marriage, and the relationship between legal context and political mobilizations. Our findings show how France's uncommon requirement to marry impacts the marriage rates of same-sex parents and puts them into an expectation to which even the most critical of marriage must conform for the sake of their families. Thus, we argue that French same-sex marriage does not just help reduce the "incomplete institutionalization" (Biblarz and Savci 2010; Manning, Brown, and Stykes 2016) of gay and lesbian families. Rather, it acts as an over institutionalization or even institutional burden that specifically targets 
same-sex couples - but not heterosexual couples - and is motivated by state anxiety to control gay and lesbian child-rearing, which is perceived as inherently untrustworthy. In this sense, much as queer scholars predicted (Bernstein and Taylor 2013; Walters 2014; Warner 1999), same-sex marriage has reinforced heterosexist norms and imposed them on gay and lesbian couples raising children in France. The state uses the law to discipline those that refuse to get married, putting their parent-child bonds in limbo. This situation has not prevented same-sex couples from attaching meaning to their marriages, similarly to other contexts (Hull 2006), or reduced activism to fight against the discrimination created by this marriage requirement. Indeed, the specific injustice for same-sex couples raising children produced by the marriage requirement has sparked criticism and continuing calls for reform. Thanks to that mobilization, as of June 2020, the French parliament is considering legislation to revise bioethics laws to allow lesbian couples access assisted reproductive techniques and to facilitate legal recognition for both mothers. Moreover, this burden on same-sex couples does not necessarily preclude them from ultimately transforming marriage from the inside, as others have already suggested they might (Polikoff 2008; Ocobock 2013; Badgett 2009).

There are several avenues for future research on the French case and beyond. First, looking at France, scholars should specifically study same-sex couples that choose not to have children and their thought processes about parenthood and marriage. All of the respondents in our sample already had children, which was their primary motivation for getting married. Couples without children who choose to marry will have other justifications for their decision and may feel more enthusiasm. It may also be that couples who choose not to have children do so precisely because they perceive a high barrier to parenthood in the French context. Second, future research in France should specifically look at the experiences of gay fathers, as scholars have done in other countries (Armesto and Shapiro 2011; Golombok and Tasker 2010; Stacey 2004; Carroll 2018). Our limited data did not allow us to talk about the men in our sample. We 
suspect that some gay fathers in France may perceive or attach different meanings to marriage than lesbian mothers because they are more likely to be raising children through co-parenting arrangements (Gross 2014; Gross, Courduriès, and Federico 2014a), which makes second parent adoption impossible. It is possible that their stances on marriage will resemble those of lesbian couples who are also in co-parenting arrangements. Finally, to build on our findings, comparative research on marriage and same-sex parents that includes the French case would be fruitful. Our findings make clear that analyses and critiques of marriage must be especially sensitive to the specific legal contexts where same-sex marriage is debated. Doing so allows us to better grasp how same-sex marriage can both open up new rights for gays and lesbians even as it reproduces forms of inequality.

\section{Bibliography}

Allen, Katherine R. 2000. "A Conscious and Inclusive Family Studies.” Journal of Marriage and Family 62 (1): 4-17.

Amato, Paul R. 2010. "Research on Divorce: Continuing Trends and New Developments." Journal of Marriage and Family 72 (3): 650-66.

Andersson, Gunnar, Turid Noack, Ane Seierstad, and Harald Weedon-Fekjær. 2006. "The Demographics of Same-Sex Marriages in Norway and Sweden.” Demography 43 (1): 79-98. https://doi.org/10.1353/dem.2006.0001.

Armesto, Jorge C., and Ester R. Shapiro. 2011. "Adoptive Gay Fathers: Transformations of the Masculine Homosexual Self." Journal of GLBT Family Studies 7 (1-2): 72-92. https://doi.org/10.1080/1550428X.2011.537202.

Badgett, M. V. Lee. 2009. When Gay People Get Married: What Happens When Societies Legalize Same-Sex Marriage. New York: NYU Press.

Barker, Nicola. 2012. Not The Marrying Kind. New York: Palgrave Macmillan.

Barker, Nicola, and Daniel Monk. 2015. From Civil Partnership to Same-Sex Marriage: Interdisciplinary Reflections. New York: Routledge.

Baunach, Dawn Michelle. 2012. "Changing Same-Sex Marriage Attitudes in America from 1988 Through 2010." Public Opinion Quarterly 76 (2): 364-78. https://doi.org/10.1093/poq/nfs022.

Bernstein, Mary, and Verta Taylor, eds. 2013. The Marrying Kind? Debating Same-Sex Marriage within the Lesbian and Gay Movement. Minneapolis, MN: University of Minnesota Press.

Biblarz, Timothy J., and Evren Savci. 2010. "Lesbian, Gay, Bisexual, and Transgender Families.” Journal of Marriage \& Family 72 (3): 480-97. https://doi.org/10.1111/j.1741-3737.2010.00714.x. 
Biblarz, Timothy J, and Judith Stacey. 2010. "Ideal Families and Social Science Ideals." Journal of Marriage and Family 72 (1): 41-44. https://doi.org/10.1111/j.17413737.2009.00682.x.

Borrillo, Daniel. 2015. "Mariage pour tous et filiation pour certains : les résistances à l'égalité des droits pour les couples de même sexe." Droit et cultures. Revue internationale interdisciplinaire, no. 69 (April): 179-220.

Bourcier, Marie-Hélène. 2012. "Cultural Translation, Politics of Disempowerment and the Reinvention of Queer Power and Politics.” Sexualities 15 (1): 93-109. https://doi.org/10.1177/1363460711432107.

Brown, Gavin. 2009. "Thinking beyond Homonormativity: Performative Explorations of Diverse Gay Economies." Environment and Planning A 41 (6): 1496-1510. https://doi.org/10.1068/a4162.

Carrington, Christopher. 2002. No Place Like Home : Relationships and Family Life Among Lesbians and Gay Men. Chicago: University of Chicago Press.

Carroll, Megan. 2018. "Gay Fathers on the Margins: Race, Class, Marital Status, and Pathway to Parenthood." Family Relations 67 (1): 104-17. https://doi.org/10.1111/fare.12300.

Chetcuti, Natacha. 2010. Se dire lesbienne: Vie de couple, sexualité, représentation de soi. Paris: Payot.

Cortina, Clara. 2016. "Demographics of Same-Sex Couples in Spain." Revista Española de Investigaciones Sociologicas, no. 153: 3-22. http://dx.doi.org/10.5477/cis/reis.153.3.

Courduriès, Jérôme. 2011. Etre en couple (gay): conjugalité et homosexualité masculine en France. Lyon, France: Presses universitaires de Lyon.

Descoutures, Virginie. 2010. Les mères lesbiennes. Paris: PUF.

Duggan, Lisa. 2002. “The New Homonormativity: The Sexual Politics of Neoliberalism.” In Materializing Democracy: Toward a Revitalized Cultural Politics, edited by Russ Castronovo and Dana D. Nelson, 175-94. Durham, NC: Duke University Press.

Fassin, Éric. 2014. "Same-Sex Marriage, Nation, and Race: French Political Logics and Rhetorics." Contemporary French Civilization 39 (3): 281-301. https://doi.org/10.3828/cfc.2014.17.

Federle, Katherine Hunt. 2005. "When Second Parent Adoption Is Not an Option." Adoption Quarterly 9 (1): 79-86. https://doi.org/10.1300/J145v09n01_05.

Gahan, Luke. 2019. "Separation and Post-Separation Parenting within Lesbian and Gay CoParenting (Guild Parented) Families." Australian and New Zealand Journal of Family Therapy 40 (1): 98-113.

Gartrell, Nanette, Henny Bos, Heidi Peyser, Amalia Deck, and Carla Rodas. 2011. "Family Characteristics, Custody Arrangements, and Adolescent Psychological Well-Being After Lesbian Mothers Break Up." Family Relations 60 (5): 572-585. https://doi.org/10.1111/j.1741-3729.2011.00667.x.

Gartrell, Nanette, Jean Hamilton, Amy Banks, Dee Mosbacher, Nancy Reed, Caroline H. Sparks, and Holly Bishop. 1996. "The National Lesbian Family Study: 1. Interviews With Prospective Mothers.” American Journal of Orthopsychiatry 66 (2): 272-81. https://doi.org/10.1037/h0080178.

Gartrell, Nanette, Carla Rodas, Amalia Deck, Heidi Peyser, and Amy Banks. 2005. "The National Lesbian Family Study: 4. Interviews With the 10-Year-Old Children." American Journal of Orthopsychiatry 75 (4): 518-524. https://doi.org/10.1037/00029432.75.4.518.

Gates, Gary J. 2011a. "Family Formation and Raising Children Among Same-Sex Couples." National Council on Family Relations FF51: F2-4. 
2011b. "How Many People Are Lesbian, Gay, Bisexual and Transgender?" Los Angeles, CA: The William's Institute. http://escholarship.org/uc/item/09h684x2. . 2015. "Marriage and Family: LGBT Individuals and Same-Sex Couples." The Future of Children 25 (2): 67-87.

Gates, Gary J., and Jason Ost. 2004. Gay and Lesbian Atlas. Washington, DC: The Urban Insitute.

Goldberg, Abbie E. 2010. "Studying Complex Families in Context." Journal of Marriage and Family 72 (1): 29-34. https://doi.org/10.1111/j.1741-3737.2009.00680.x.

Goldberg, Abbie E., Nanette K. Gartrell, and Gary J. Gates. 2014. "Research Report on LGBParent Families." Los Angeles, CA: Williams Institute UCLA.

Golombok, Susan, and Fiona Tasker. 2010. "Gay Fathers." In Role of the Father in Child Development, edited by Michael E. Lamb, 319-40. New York: Wiley.

Gross, Martine. 2011. Choisir la paternité gay. Toulouse, France: Eres.

- 2012. Qu'est-ce que l'homoparentalité? Paris: Payot.

2014. "Les tiers de procréation dans les familles homoparentales." Recherches familiales 11 (1): 19-30.

_. 2015. L'Homoparentalité: idées reçues sur l'homoparentalité. Le Cavalier Bleu Editions.

—. 2017. "L'accès Des Couples de Femmes à La Procréation Médicalement Assistée: Questions de Filiation." Droit et Cultures. Revue Internationale Interdisciplinaire, no. 73: 111-123.

Gross, Martine, Jérôme Courduriès, and Ainhoa de Federico. 2014a. "Le recours à l'AMP dans les familles homoparentales : état des lieux. Résultats d'une enquête menée en 2012." Socio-logos, no. 9 (February): 1-30.

. 2014b. "Morphologie des familles homoparentales en France en 2012." In

Homosexualité et parenté, by Jérôme Courduriès and Agnès Fine, 205-12. Armand Colin.

Heckathorn, Douglas D. 2002. "Respondent-Driven Sampling II: Deriving Valid Population Estimates from Chain-Referral Samples of Hidden Populations." Social Problems 49 (1): 11-34. https://doi.org/10.1525/sp.2002.49.1.11.

Hull, Kathleen E. 2006. Same-Sex Marriage: The Cultural Politics of Love and Law. Cambridge, UK: Cambridge University Press.

Hull, Kathleen E., and Timothy A. Ortyl. 2019. "Conventional and Cutting-Edge: Definitions of Family in LGBT Communities." Sexuality Research and Social Policy 16 (1): 3143. https://doi.org/10.1007/s13178-018-0324-2.

Kalmijn, Matthijs, Anneke Loeve, and Dorien Manting. 2007. "Income Dynamics in Couples and the Dissolution of Marriage and Cohabitation." Demography 44 (1): 159-79.

Kolk, Martin, and Gunnar Andersson. 2018. "Two Decades of Same-Sex Marriage in Sweden: Of Developments in Marriage, Childbearing and Divorce.” 2018:9. Stockholm Research Reports in Demography. Stockholm University.

Kurdek, Lawrence A. 1998. "Relationship Outcomes and Their Predictors: Longitudinal Evidence from Heterosexual Married, Gay Cohabiting, and Lesbian Cohabiting Couples." Journal of Marriage \& Family 60 (3): 553-68.

Lauster, Nathanael, and Adam Easterbrook. 2011. "No Room for New Families? A Field Experiment Measuring Rental Discrimination against Same-Sex Couples and Single Parents." Social Problems 58 (3): 389-409.

Malmquist, Anna. 2015. “A Crucial but Strenuous Process: Female Same-Sex Couples' Reflections on Second-Parent Adoption." Journal of GLBT Family Studies 11 (4): 351-74. https://doi.org/10.1080/1550428X.2015.1019169. 
Malmquist, Anna, and Nelson K. Zetterqvist. 2013. "Gay and Lesbian Parents.” In Oxford Bibliographies in Childhood Studies, edited by Heather Montgomery, 1-18. New York, NY: Oxford University Press.

Manning, Wendy D., Susan L. Brown, and J. Bart Stykes. 2016. "Same-Sex and DifferentSex Cohabiting Couple Relationship Stability." Demography 53 (4): 937-53. https://doi.org/10.1007/s13524-016-0490-x.

Manning, Wendy D., Marshal Neal Fettro, and Esther Lamidi. 2014. "Child Well-Being in Same-Sex Parent Families: Review of Research Prepared for American Sociological Association Amicus Brief." Population Research and Policy Review 33 (4): 485-502. https://doi.org/10.1007/s11113-014-9329-6.

Messina, Roberta, and Salvatore D'Amore. 2018. "Adoption by Lesbians and Gay Men in Europe: Challenges and Barriers on the Journey to Adoption." Adoption Quarterly, 123.

Mezey, Nancy J. 2014. LGBT Families. New York: SAGE Publications.

Mezey, Susan Gluck. 2009. Gay Families and the Courts: The Quest for Equal Rights. Lanham, MD: Rowman \& Littlefield Publishers.

Moore, Mignon R. 2011. Invisible Families: Gay Identities, Relationships, and Motherhood Among Black Women. Los Angeles, CA: University of California Press.

Moore, Mignon R., and Michael Stambolis-Ruhstorfer. 2013. "LGBT Sexuality and Families at the Start of the Twenty-First Century." Annual Review of Sociology 39 (1): 491507. https://doi.org/10.1146/annurev-soc-071312-145643.

Ocobock, Abigail. 2013. "The Power and Limits of Marriage: Married Gay Men's Family Relationships." Journal of Marriage and Family 75 (1): 191-205. https://doi.org/10.1111/j.1741-3737.2012.01032.x. . 2018. "Status or Access? The Impact of Marriage on Lesbian, Gay, Bisexual, and Queer Community Change." Journal of Marriage and Family 80 (2): 367-82. https://doi.org/10.1111/jomf.12468.

Olsen, Kristine A. 2014. "Telling Our Stories: Narrative and Framing in the Movement for Same-Sex Marriage.” Social Movement Studies 13 (2): 248-66. https://doi.org/10.1080/14742837.2013.842464.

Paternotte, David. 2011. Revendiquer le “mariage gay”: Belgique, France, Espagne. Bruxelles: Editions de l'Université de Bruxelles.

Perrin, Ellen C. 2002. "Technical Report: Coparent or Second-Parent Adoption by Same-Sex Parents." Pediatrics 109 (2): 341-44.

Pew Research Center. 2010. "Survey of LGBT Americans. The Decline of Marriage And Rise of New Families." Washington, DC: Pew Research Center. http://www.pewsocialtrends.org/2010/11/18/the-decline-of-marriage-and-rise-of-newfamilies/.

Polikoff, Nancy D. 2008. Beyond (Straight and Gay) Marriage: Valuing All Families Under the Law. Boston, MA: Beacon Press.

Powell, Brian, Catherine Bolzendahl, Claudia Geist, and Lala Carr Steelman. 2010. Counted Out: Same-Sex Relations and Americans' Definitions of Family. Ithaca, NY: Russel Sage Foundation.

Powell, Brian, Laura Hamilton, Bianca Manago, and Simon Cheng. 2016. "Implications of Changing Family Forms for Children.” Annual Review of Sociology 42 (1): 301-22. https://doi.org/10.1146/annurev-soc-081715-074444.

Rault, Wilfried. 2019. "Is the Civil Solidarity Pact the Future of Marriage? The Several Meanings of the French Civil Union." International Journal of Law, Policy and the Family 33 (2): 139-59. https://doi.org/10.1093/lawfam/ebz001. 
Robcis, Camille. 2015. "Liberté, Égalité, Hétérosexualité: Race and Reproduction in the French Gay Marriage Debates." Constellations 22 (3): 447-61. https://doi.org/10.1111/1467-8675.12168.

Rosenfeld, Michael J. 2014. "Couple Longevity in the Era of Same-Sex Marriage in the United States." Journal of Marriage and Family 76 (5): 905-18. https://doi.org/10.1111/jomf.12141.

Ross, Helen, Karen Gask, and Ann Berrington. 2011. "Civil Partnerships Five Years On." Population Trends 145 (1): 172-202. https://doi.org/10.1057/pt.2011.23.

Stacey, Judith. 2004. "Cruising to Familyland: Gay Hypergamy and Rainbow Kinship." Current Sociology 52 (2): 181-97. https://doi.org/10.1177/0011392104041807.

Stambolis-Ruhstorfer, Michael. 2015. "The Culture of Knowledge: Constructing 'Expertise' in Legal Debates on Marriage and Kinship for Same-Sex Couples in France and the United States." PhD Dissertation, Los Angeles, CA: University of California Los Angeles and Ecole des Hautes Etudes en Sciences Sociales.

Stambolis-Ruhstorfer, Michael, and Josselin Tricou. 2017. "Resisting 'Gender Theory' in France: A Fulcrum for Religious Action in a Secular Society." In Anti-Gender Campaigns in Europe, edited by Roman Kuhar and David Paternotte, 79-98. London: Rowman \& Littlefield.

Waaldijk, Kees, Daniel Damonzé, Marie Digoix, Marina Franchi, Natalie Nikolina, José Ignacio Pichardo Galán, Giulia Selmi, et al. 2017. "The LawsAndFamilies Database Aspects of Legal Family Formats for Same-Sex and Different-Sex Couples." Paris:

INED. http://www.familiesandsocieties.eu/wpcontent/uploads/2017/04/WorkingPaper75.pdf.

Walters, Suzanna Danuta. 2014. The Tolerance Trap: How God, Genes, and Good Intentions Are Sabotaging Gay Equality. New York: NYU Press.

Warner, Michael. 1999. "Normal and Normaller: Beyond Gay Marriage." GLQ: A Journal of Lesbian and Gay Studies 5 (2): 119-71.

Wiik, Kenneth Aarskaug, Ane Seierstad, and Turid Noack. 2014. "Divorce in Norwegian Same-Sex Marriages and Registered Partnerships: The Role of Children." Journal of Marriage and Family 76 (5): 919-29. https://doi.org/10.1111/jomf.12132. 